\title{
The Influences of Supplier Selection and Partnership Quality on Buyer-Supplier Relationship and Firm Performance on Small and Medium Restaurants in Greater Jakarta
}

\author{
Hugo Priladi ${ }^{1}$, Ratih Dyah Kusumastuti ${ }^{2}$ \\ Department of Management, Faculty of Economics and Business, Universitas Indonesia, \\ Kampus UI Depok, Indonesia ${ }^{1,2}$ \\ Hugop2104@gmail.com¹, ratih.dyah@ui.ac.id ${ }^{2}$
}

\begin{abstract}
All companies require all factors of production, including labour and raw materials, to provide goods and services to their customers. The raw materials are usually obtained from the suppliers, while labour and other services can be managed in-house or obtained through outsourcing activities. The objective of this research is specifically to investigate the influences of supplier selection on partnership quality, partnership quality and supplier selection on buyer-supplier relationship (BSR) and firm performance of small and medium restaurants in Greater Jakarta, Indonesia. A questionnaire is developed and distributed through a field survey to 96 respondents who are restaurant owners/managers in Greater Jakarta. Partial least squares structural equation modeling (PLS-SEM) is used to analyze the survey data. The results show that supplier selection has influences on partnership quality and BSR, while partnership quality does not affect BSR, and BSR has an influence on firm performance.
\end{abstract}

Keywords: Partnership Quality; Buyer-supplier relationship; Supplier selection; Firm performance.

\section{Introduction}

The restaurant sector is a part of the service industry that has a unique characteristic due to the strong relationship between services and facilities. Restaurants create tangible products in the form of food and beverages as well as intangible products, namely the services, which are immediately consumed by the customers.

Restaurants need raw materials and other services for their operational activities, which are usually purchased from suppliers. In order to find suitable suppliers, restaurants must conduct supplier selection, which process is very critical to product quality and customer satisfaction level [1]. Determination of suppliers is conducted based on the financial capability of the suppliers, as well as, stability, payment term and future order [2].

In order to have a successful relationship with suppliers, both restaurants and suppliers should pay attention on the partnership quality. Partnership as strategic relationship between 
independent companies that share the same goals and profits, and are dependent on each other[3]. Partnership quality is positively influenced by participation, communication quality, information sharing and supports from the top management team[4].

Good supplier selection and partnership quality are elemental to achieve a successful buyer and supplier relationship. The advantages of having a successful buyer and supplier relationship at the operational level include increased quality, reduced cost, or a combination of both, while at the strategic level include continuous improvement of products and innovation that lead to improved competitive advantage, increased market share, and firm performance[2].

However, suppliers can cause problems. First, suppliers create dependency, and reducing or even eliminating company's ability to purchase raw materials[5], as well as causing loss of control for quality and delivery [6]. Second, partnership with suppliers may not last in the longterm due to suppliers' operational capability which is inadequate or not adjusted to the company's changes [7]. Third, high suppliers' bargaining power when the raw materials are unique [8]. Therefore, it is important to understand factors that affect the success of company's relationship with their suppliers, and their firm performance.

In Indonesia, the restaurant and catering sector contributed about $2.4 \%$ of the country's GDP or about IDR 326.1 trillion in 2017, and the sector grew at an average of about 5\% in the period of 2014-2017 (see Fig. 1) [9]. In Jakarta, in particular, there were about 2009 small and medium restaurants in Jakarta in 2014, and 53\% of the residents dined in restaurants with a frequency of 1 to 6 visits per person per month[10].

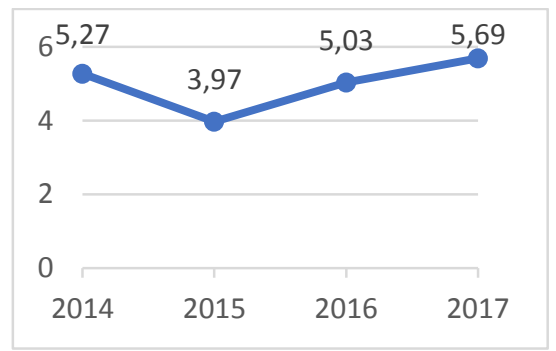

Fig. 1. The percentage of growth rate of restaurant and catering sector in 2014-2017[9].

The objective of this paper is to investigate the influences of partnership quality and supplier selection on the success buyer-supplier relationship and performance of small and medium restaurants in Greater Jakarta. This study is expected to contribute by providing insights on the role of suppliers and partnership in influencing the relationship between both parties and the performance of companies in the restaurant sector in the area.

\section{Method}

The research is conducted by using quantitative approach and the data is collected by using a survey. Concerning the partnership quality variable, as in [4], it has 5 dimensions, namely trust, business understanding, benefit and risk share, conflict, and commitment, with a total of 14 indicators. Regarding Buyer-Supplier Relationship variable, the indicators are six [11]. Lastly, the number of indicators for Firm Performance is three, and they are adopted from [12]. In total, the number of indicators is 30 .

The unit of analysis in this research is restaurant. We use purposive sampling, whereby the restaurants are chosen based on information from the local government. If the restaurant is a part or the restaurant chain, we only have one respondent from the chain as we assume that the 
entire chain will have similar suppliers. Our sample consists of 96 restaurants in the area of Jakarta, Depok and Bogor. The respondents are restaurant's owners/managers/supervisors.

Pre-test is carried out to check whether the questions are understood by the respondents. The pre-test data is analyzed using SPSS 22 software. The results show that all variables are reliable, however, there are several indicators which factor loading are less than 0.5 , thus, we rephrase the questions to improve the understanding. Field survey is then conducted, and the results are analyzed using Partial Least Squares Structural Equation Modeling (PLS-SEM) with the SmartPLS 3 software. We use PLS-SEM, because it performs well with small sample sizes [13]. The recommended minimum sample size depends on the number of maximum arrows pointing at a construct, the intended statistical power and $R^{2}$ value, and the probability of error[13]. In this case, since the maximum number of arrows pointing at a construct is 2 , it requires at least 52 observations to achieve a statistical power of $80 \%$ for detecting $R^{2}$ values of at least 0.25 (with a $5 \%$ probability of error).

\section{Result}

Profile of the respondents is presented in Table 1. It can be seen that most respondents are located in Bogor (satellite city of Jakarta), have revenue between IDR 300 million (around USD 21 thousand) and 2.5 billion (around USD 173 thousand) in 2017 or considered as small enterprises (based on the Government Regulation Number 20 Year 2008), the number of suppliers is up to 5, and use open tender in the process of selecting suppliers.

We perform CFA on Partnership Quality variable. Iteratively, we exclude indicators that have loading factor below 0.5 and dimensions that have average variance extracted (AVE) less than 0.50 . We then test the convergent validity of the model, and further excluding indicators that have loading factor below 0.5 . In the resulting model, all constructs have good validity and reliability, with Cronbach's alpha higher than 0.7 , composite reliability more than 0.70 dan AVE more than 0.50 .

Hypothesis testing is then conducted, and the results can be seen in Table 2. The results indicate that out of four hypotheses, three hypotheses ( $\mathrm{H} 1, \mathrm{H} 3$, and $\mathrm{H} 4)$ are supported by data, and one hypothesis $(\mathrm{H} 2)$ is not supported by data as the t-statistics is less than 1.96 and p-value is bigger than 0.05 .

Table 1. Respondents Profile

\begin{tabular}{|c|c|c|c|}
\hline \multicolumn{2}{|c|}{ Descriptions } & Frequency & Percentage \\
\hline \multirow{4}{*}{$\begin{array}{l}\text { Current } \\
\text { position }\end{array}$} & Owner & 11 & $11 \%$ \\
\hline & Manager & 57 & $59 \%$ \\
\hline & Supervisor & 28 & $29 \%$ \\
\hline & Total & 96 & $100 \%$ \\
\hline \multirow{4}{*}{$\begin{array}{l}\text { he } \\
\text { restaurant } \\
\text { has been } \\
\text { established } \\
\text { for }\end{array}$} & $\begin{array}{l}\text { Less than } 3 \\
\text { years }\end{array}$ & 31 & $32 \%$ \\
\hline & $3-5$ years & 36 & $38 \%$ \\
\hline & $\begin{array}{l}\text { More than } 5 \\
\text { years }\end{array}$ & 29 & $30 \%$ \\
\hline & Total & 96 & $100 \%$ \\
\hline \multirow{4}{*}{$\begin{array}{l}\text { Location of } \\
\text { the } \\
\text { restaurant }\end{array}$} & Jakarta & 22 & $23 \%$ \\
\hline & Depok & 16 & $17 \%$ \\
\hline & Bogor & 58 & $60 \%$ \\
\hline & Total & 96 & $100 \%$ \\
\hline \multirow{4}{*}{$\begin{array}{l}\text { Number of } \\
\text { outlets }\end{array}$} & $1-5$ & 70 & $73 \%$ \\
\hline & $6-10$ & 12 & $13 \%$ \\
\hline & More than 10 & 14 & $15 \%$ \\
\hline & Total & 96 & $100 \%$ \\
\hline
\end{tabular}




\begin{tabular}{|l|l|c|c|}
\hline \multirow{3}{*}{$\begin{array}{l}\text { Sales } \\
\text { revenue in }\end{array} 017$} & $\begin{array}{l}\text { Less than or } \\
\text { equal to IDR } \\
300 \text { million }\end{array}$ & 20 & $21 \%$ \\
\cline { 2 - 4 } & $\begin{array}{l}\text { Between IDR } \\
300 \text { million - } \\
2.5 \text { billion }\end{array}$ & 63 & $66 \%$ \\
\cline { 2 - 4 } & $\begin{array}{l}\text { Between IDR } \\
2.5-50 \\
\text { billion }\end{array}$ & 13 & $14 \%$ \\
\cline { 2 - 4 } & Total & 96 & $100 \%$ \\
\hline \multirow{5}{*}{$\begin{array}{l}\text { Number of } \\
\text { suppliers }\end{array}$} & $1-5$ & 61 & $64 \%$ \\
\cline { 2 - 4 } & $6-10$ & 25 & $26 \%$ \\
\cline { 2 - 4 } & More than 10 & 10 & $10 \%$ \\
\cline { 2 - 4 } & Total & 96 & $100 \%$ \\
\hline \multirow{3}{*}{$\begin{array}{l}\text { Supplier } \\
\text { selection } \\
\text { process }\end{array}$} & Open tender & 50 & $52 \%$ \\
\cline { 2 - 4 } & Closed tender & 18 & $19 \%$ \\
\cline { 2 - 4 } & Direct & 28 & $29 \%$ \\
\cline { 2 - 4 } & Toppointment & 96 & $100 \%$ \\
\hline
\end{tabular}

Table 2. Path coefficients

\begin{tabular}{|l|l|l|l|l|c|}
\hline & $\begin{array}{c}\text { Original } \\
\text { Sample } \\
(\mathbf{O})\end{array}$ & $\begin{array}{c}\text { Sample } \\
\text { Mean } \\
(\mathbf{M})\end{array}$ & $\begin{array}{c}\text { Std. } \\
\text { Dev. }\end{array}$ & $\begin{array}{c}\text { T- } \\
\text { Value }\end{array}$ & $\begin{array}{c}\text { P- } \\
\text { Value }\end{array}$ \\
\hline $\begin{array}{l}\text { SS -> } \\
\text { Parquil }\end{array}$ & 0.735 & 0.741 & 0.053 & $\mathbf{1 3 . 7 9 5}$ & $\mathbf{0 . 0 0 0}$ \\
\hline $\begin{array}{l}\text { Parquil- } \\
\text { > BSR }\end{array}$ & -.229 & -.212 & 0.190 & 1.207 & 0.114 \\
\hline $\begin{array}{l}\text { SS -> } \\
\text { BSR }\end{array}$ & 0.655 & 0.653 & 0.164 & $\mathbf{3 . 9 8 9}$ & $\mathbf{0 . 0 0 0}$ \\
\hline $\begin{array}{l}\text { BSR -> } \\
\text { Perf }\end{array}$ & 0.465 & 0.488 & 0.087 & $\mathbf{5 . 3 5 3}$ & $\mathbf{0 . 0 0 0}$ \\
\hline
\end{tabular}

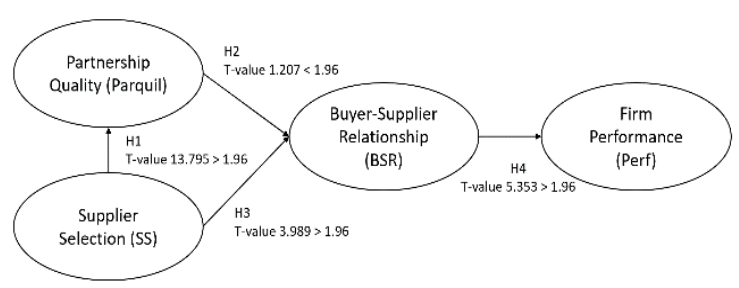

Fig. 2. Results of hypotheses test

\section{Discussion}

The results show that for t-value for the path from Supplier Selection to Partnership Quality is 5.353 with p-value equals to 0.000 . This indicates that SS has positive influence on Partnership Quality (Hypothesis 1 is supported by data)[14]. The importance of the relationship is particularly high after the supplier selection proses is completed. Good supplier selection will result in good and reliable suppliers that will lead to good quality of raw materials and reliable delivery. The requirements stated in supplier selection process will be realized in terms of contract between both parties that results in shared responsibility, risk and benefit. The relationship between suppliers and buyers changes from win-lose negotiation to partnership for 
mutual benefit[15]. The survey results show that $29 \%$ of respondents state that supplier selection is done through direct appointment, indicating that trust has already been existed between restaurants and their suppliers that is further manifested in commitment between both parties.

The results also show that the t-value for the path from Partnership Quality to BuyerSupplier Relationship is 1.207 with p-value that is higher than 0.05 , or Hypothesis 2 is not supported by data (Partnership Quality has no positive influence on the BSR). Partnership is vulnerable to the dynamics of both parties[16]. When both parties have different expectations, the situation may affect the partnership quality. Furthermore, as can be seen in Table 2, 52\% of the respondents, state that they select their suppliers through an open tender mechanism. This indicates a tight supplier selection process that results in formal relationship between buyers and suppliers. In the measurement model, Partnership Quality is represented by Trust and Commitment dimensions, while in the construct of BSR, communicating important issue with main supplier has the highest loading factor (0.819). Hence, the results can be interpreted that the restaurants will always communicate important issues with the main supplier to ensure smooth operations regardless of the level of trust and commitment between both parties.

The results also reveal that the t-value for the path from Supplier Selection to BSR is 3.989 with p-value equals to 0.000 or Supplier Selection has positive influence on BSR (Hypothesis 3 is supported by data). That state supplier selection can support buyer-supplier relationship[2]. In the context of restaurant industry, suppliers' ability to provide goods and services that meet the required specifications (loading factor 0.827) plays an important role in ensuring the success operations of the restaurants. Thus, a good supplier selection process will result in good and reliable suppliers for the restaurants, leading to a successful buyer-supplier relationship.

This research also finds that the t-value for the path from BSR to Firm Performance is 5.353, with p-value of 0.000 or BSR has a positive influence on Firm Performance (Hypothesis 4 is supported by data)[17];[2]. They say that companies which have cooperative relationships with their suppliers expect benefit from the relationships. In the context of the restaurant industry, the good relationships between restaurants and their suppliers will result in good quality of raw materials and smooth restaurant operations that support the restaurants' performances.

\section{Conclusion}

The study aims to analyze the influence of Supplier Selection and Partnership Quality on Buyer-Supplier Relationship and Firm Performance, with the context of small and medium restaurants in Greater Jakarta. We gather primary data from 96 restaurants owners/managers by distributing questionnaire and the results are analyzed using partial least squares structural equation method.

The results show that Supplier selection has positive influence on Partnership Quality and Buyer-Supplier Relationship, while Partnership Quality has no positive influence on BuyerSupplier Relationship, and Buyer-Supplier Relationship has positive influence on Firm Performance. The results indicate that in the restaurant industry, a good supplier selection will result in reliable suppliers that can provide goods and services with specifications that meet the restaurants' requirements, and in turn, this will result in a successful buyer-supplier relationship that lead to good firm performance.

This research has limitations. The firm performance is measured based on perception due to the difficulty of gathering financial data from the restaurants. In the future research, this construct may be measured using secondary data to allow comprehensive analysis of the results. Furthermore, the sample size can be enlarged with proportional ratio of respondents between 
cities in Greater Jakarta, so that the results can better represent the restaurant industry in the area.

\section{References}

[1] H. C. K. Lin, M. C. Chen, dan and C. K. Chang, "Assessing the effectiveness of learning solid geometry by using an augmented reality-assisted learning system," Interact Learn Env., vol. 23, no. 6, hlm. 799-810, 2015.

[2] R. V. Kannan dan K. C. Tan, "Buyer-Supplier Relationships: The Impact Of Supplier Selection and Buyer-Supplier Engagement On Relationship and Firm Performance," J. Phys. Distrib. Logist. Manag., vol. 36, no. 10, hlm. 755-775, 2006.

[3] J. Mohr dan R. Spekman, "Characteristics Of Partnership Success: Partnership Attributes, Communication, Behavior, and Conflict Resolution Techniques," Strateg. Manag. J., vol. 15, no. 135-152, hlm. 41, 1994.

[4] J. N. Lee dan Y. G. Kim, "Effect Of Partnership Quality On IS Outsourcing Success: Conceptual Framework And Empirical Validation," J. Manag. Inf. Syst., vol. 15, no. 4, hlm. 29-61, 1999.

[5] T. Bolat dan Ö. Y1lmaz, "The Relationship Between Outsourcing and Organizational Performance: Is It Myth Or Reality For the Hotel Sector?," Int. J. Contemp. Hosp. Manag., vol. 21, no. 1, hlm. 7-23, 2009.

[6] J. Heizer, B. Render, dan C. Munson, Operations Management Sustainability and Supply Chain Management. 12th. Boston: Pearson Education Inc, 2017.

[7] M. Kotabe, X. Martin, dan H. Domoto, "Gaining From Vertical Partnerships: Knowledge Transfer, Relationship Duration, and Supplier Performance Improvement In The U.S. and Japanese Automotive Industries," Strateg. Manag. J., vol. 24, hlm. 293-316, 2003.

[8] M. Porter, "The Five Competitive Forces That Shape Strategy," Harv. Bus. Rev., hlm. 25-40, Jan 2008.

[9] rizky Natassia, "Pengaruh Gaya Kepemimpinan Dan Motivasi Kerja Terhadap Kinerja Karyawan Badan Pusat Statistik (BPS) Kota Padang," economica, vol. 2, no. 2, hlm. 134143, Jul 2015.

[10] G. of Jakarta, Food And Catering Sector Data In Jakarta. 2016.

[11] S. A. Carr dan J. N. Pearson, "Strategically Managed Buyer-Supplier Relationships and Performance Outcomes," J. Oper. Manag., vol. 17, hlm. 497-519, 1999.

[12] O. F. Bustinza, D. A. Aranda, L. Gutierrez-Gutierrez, dan L.G., "Outsourcing, Competitive Capabilities And Performance: An Empirical Study In Service Firms.," J Prod. Econ., vol. 126, hlm. 276-288, 2010.

[13] J. F. Hair, G. T. M. Hult, C. M. Ringle, dan M. Sarstedt, A Primer on Partial Least Squares Structural Equation Modeling. Thousand Oaks: Sage, 2013.

[14] R. M. Monczka, P. L. Carter, T. V. Scannel, dan J. R. Carter, Implementing Supplier Innovations: Case Study Findings. Tempe, AZ: CAPS Research, 2010.

[15] A. P. Kakouris, G. Polychronopoulos, dan S. Binioris, "Outsourcing Decision And The Purchasing Process: A Systems-Oriented Approach,” Mark. Intell. Plan., vol. 24, no. 7, hlm. 708-729, 2006.

[16] A. Campbell, "Buyer - Supplier Partnerships: Flip Sides Of The Same Coin?," J. Bus. Ind. Mark., vol. 12, no. 6, hlm. 417-434, 1997.

[17] F. R. Dwyer, P. H. Schurr, dan S. Oh, "Developing Buyer-Seller Relationships," J. Mark., vol. 51, hlm. 2), 1987. 